\title{
Ductus urachus persistens laparoszkópos eltávolítása
}

\author{
Lukovich Péter dr. - Harsányi László dr.
}

Semmelweis Egyetem, Általános Orvostudományi Kar, I. Sebészeti Klinika, Budapest

\begin{abstract}
A dustus urachus a foetalis életben az allantoist és a hólyagot összekötő fibromuscularis vezeték, amely általában a 4-5. gestatiós hónapban elzáródik. Az urachus nem teljes záródása a születéskor még fiziológiásnak tekinthető, nyitva maradása a köldök recidiváló gyulladásához, váladékozásához vezethet. Diagnózisában az ultrahang az elsődlegesen választandó vizsgálóeszköz. A szerzők 19 éves, elhízott nőbeteg kórtörténetét ismertetik, akinél a köldökváladékozás hátterében a hasi ultrahangvizsgálat ductus urachus persistenst írt le. Három portból végzett laparoszkópos mútét során a peritoneum meghasítása után láthatóvá vált vezetéket a hólyagkupoláig felszabadították, majd egy műanyag klippel distalisan elzárták és kiirtották. A műtéti idő 38 perc volt. A posztoperatív szakban a beteg egy alkalommal igényelt minor analgetikumot, és a mútét másnapján távozott a klinikáról. A szerzők kiemelik, hogy a ductus urachus persistens mútéti ellátása laparoszkópos technikával javasolt; az urachus maradványa az első hasfalon a 30 fokos optikával, nagyított képen jobban látható, végig követhető a Retzius-spatiumtól a köldökig, és esztétikailag is szebb eredmény érhető el. Orv. Hetil., 2015, 156(38), 1547-1550.
\end{abstract}

Kulcsszavak: urachusfistula, laparoszkópos reszekció, köldökváladékozás

\section{Laparoscopic resection of the urachus persistent}

\section{Case report}

The urachus in the foetus is a fibromuscular duct, which connects the allantois to the bladder and it is usually occluded in the 4-5th gestation months. Incomplete occlusion of the urachus at the time of birth is considered to be physiological, but later it can lead to recurrent discharge and inflammation of the umbilicus. To establish the diagnosis, ultrasound is the first examination of choice. A 19-year old obese female patient presented with umbilical discharge, and a persistent urachus was detected by ultrasound. After incision of the peritoneum the duct was excised from the umbilicus to the dome of the bladder by 3-port laparoscopy where the duct was clipped. The operation time was 38 minutes. The patient minor analgesia on one single occasion in the postoperative period and was discharged on the first postoperative day. The authors recommend laparoscopic operation for the urachal remnant; the enlarged duct on the ventral abdominal wall can be better detected from the umbilicus to the Retzius spatium with 30-degree camera, and the cosmetic outcome is also more favourable.

Keywords: urachal remnant, laparoscopic resection, umbilical discharge

Lukovich, P., Harsányi, L. [Laparoscopic resection of the urachus persistent. Case report]. Orv. Hetil., 2015, 156(38), 1547-1550.

(Beérkezett: 2015. július 1.; elfogadva: 2015. július 30.)

A ductus urachus a foetalis életben az allantoist és a hólyagot összekötő fibromuscularis vezeték, amely általában a 4-5. gestatiós hónapban - ahogy a hólyag leszáll a kismedencébe - megnyúlik és elzáródik. A heges vezeték a transversalis fascia és a peritoneum között helyezkedik el, és anatómiailag a ligamentum mediana umbilicalisnak felel meg. A vezeték inkomplett elzáródását a következőképpen nevezzük: urachus persistens, ha a köldök és a hólyag között végig nyitva marad a vezeték; urachus sinus, ha az umbilicalis szakasz marad nyitva; urachusdiverticulum, amennyiben csak a hólyagkupolánál elhelyezkedő rész marad nyitva, urachuscysta, ha a centrális rész marad 
nyitva, illetve urachushír, ha az egész vezeték elzáródik és húrként tapintható.

A különböző formák előfordulási gyakorisága a következő: nyitott urachus $10-48 \%$, urachuscysta $31-43 \%$, urachus sinus $18-43 \%$ és urachusdiverticulum $3-4 \%$ [1].

$\mathrm{Az}$ urachus nyitva maradása az esetek harmadában az urogenitalis rendszer valamilyen egyéb fejlődési rendellenességével jár együtt (vesicoureteralis reflux, hydronephrosis, ureteropelvic-junctio obstrukciója vagy ovariumcysta) [2].

$\mathrm{Az}$ urachus nem teljes záródása - fóleg a születéskor - még fiziológiásnak tekinthetó, és amennyiben nem okoz tüneteket, 6 hónapos életkor előtt nem igényel semmilyen beavatkozást [2], egyéves kor alatt is csak akkor javasolt sebészeti ellátása, ha a panaszok kiújulnak $[3,4] .16$ éves kor alatt a visszatérố urológiai panaszok hátterében ugyanakkor 60\%-ban az urachus fejlődési rendellenessége igazolható [5].

$\mathrm{Az}$ életkor előrehaladtával egyre csökken az esélye, hogy panaszokat okozzon: az umbilicalis vég nyitva maradása a köldök recidiváló gyulladásához, váladékozásához vezethet (amelynek kórokozója általában a Staphylococcus aureus), de hasi fájdalmat és hólyagretenciót is okozhat.

Az urachus rosszindulatú elváltozása ritka, 1970-ben Blichert-Toft és Nielsen összesen 315 esetet gyújtött öszsze és publikált [6]. Egyes szerzők szerint ez a fejlődési rendellenesség áll a hólyagtumorok $0,17-0,34 \%$-ának hátterében is $[7,8]$, ezért mútéti eltávolítását javasolják. Ugyanakkor más szerzők szerint nincs összefüggés az urachus nyitva maradása és a hólyagtumor között [2].

Gyanú esetén az ultrahang az elsődlegesen választandó vizsgálóeszköz, s mivel közvetlenül a hasfal mögött helyezkedik el, a bélgázok nem zavarják a vizsgálatot [9]. Így a vizsgálat pontossága 61,1 és 91,3\% közötti [10, $11]$. Kétség esetén komputertomográfiás vizsgálat, illetve urocisztográfia segíthet a diagnózis felállításában.

Differenciáldiagnosztikai szempontból omphalitis, köldökvéna-gyulladás, illetve nőkben endometriosis jön szóba.

Esetismertetésünk több szakma érdeklődésére is számot tarthat: fejlődési rendellenességként a gyermekgyógyászok, a gyermeksebészek, az urológusok találkozhatnak gyakran a kórképpel. Váladékozó köldök miatt az ultrahangvizsgálatot végző radiológus kollégának ilyen esetben gondolnia kell az urachusfistulára, végül felnőttkorban jelentkező panaszok esetén általában a hasi sebész feladata a betegség gyógyítása.

Hazai közlemény urachusfistuláról 1954-ben a Magyar Sebészetben [12], illetve 1992-ben az Orvosi Hetilapban jelent meg utoljára [13]. Laparoszkópos megoldásról ez az első közlemény Magyarországon.

\section{Esetismertetés}

A 19 éves, elhízott (BMI: $33,5 \mathrm{~kg} / \mathrm{m}^{2}$ ) nőbeteget visszatérő köldökváladékozás miatt vizsgálták. Hasi ultrahang- vizsgálata a köldök és a hólyag között, supraperitonealisan elhelyezkedő $2 \mathrm{~mm}$-es fistulajáratot, ductus urachus persistenst írt le.

A beteget laparoszkóppal operáltuk meg. A Veres-tút, majd az elsô, $10 \mathrm{~mm}$-es trokárt a 30 fokos optikának a bal subcostalis régióban vezettük be. Ezt követően a köldök magasságában lateralisan, illetve epigastrialisan egyegy $5 \mathrm{~mm}$-es munkatrokárt helyeztünk be. A köldökfistulába szondát vezettünk, majd a középvonalban meghasítva a peritoneumot, a praeperitonealis zsírban láthatóvá vált a vezeték, amelyet lefelé a hólyagkupoláig felszabadítottunk, majd múagyag klippel distalisan elzártunk és kiirtottunk (1. ábra).

A mútéti idő 38 perc volt. A posztoperatív szakban a beteg egy alkalommal igényelt minor analgetikumot, a mútét másnapján távozott a klinikáról. Szövődményt az elmúlt két hónapban nem észleltünk, köldökváladékozása megszúnt (2. ábra). A szövettani vizsgálat a fibrodiposus állományban heges, sejtszegény kötőszövetes állományrészt mutatott ki, amelynek felszínén kis területen köbös hámjellegú borítás volt felfedezhető. Malignitásra utaló jel nem volt. A képlet perzisztáló urachusnak megfelelt (dr. Istók Roland).

\section{Megbeszélés}

A ductus urachus persistens mútéti ellátásakor a ductus radikális kiirtása a cél. Laparoszkópos ellátásáról viszonylag korán, már 1993-ban megjelent az első közlemény [14], de olvasható közlemény single incision laparoszkópos technika alkalmazásáról is [15]. A laparoszkópos technika elónyei itt is tetten érhetốk: az urachus maradványa az első hasfalon a 30 fokos optikával, nagyított képen jobban látható, és végig követhető a Retzius-spatiumtól a köldökig. Esztétikailag szebb eredmény érhető el [16], és az esetlegesen gyulladt köldök is elkerülhető ily módon. Esetünkben a beteg obesitasa is a laparoszkópos megoldás mellett szólt.

Egy centrumban laparoszkóppal operált több mint 4 betegről a cikk megírásáig 8 közlemény számolt be, ezekben összesen 72 beteg mútétjéról számoltak be [16]. Ezenkívül számos esetismertetés szól laparoszkópos mútéti megoldásról.

A mútétek kivitelezése általában három trokárból történik, epigastrialisan bevezetett kamerával, illetve jobb és bal oldalon bevezetett munkatrokárokkal. Más szerző́k jobb vagy bal oldalon vezetik be mindhárom trokárt. Mindenképpen elkerülendő a köldök, amely gyulladás hiányában is potenciálisan fertőzöttnek tekinthető. Magunk a mútét során azért a bal oldalon, subcostalisan (Palmer-pont) vezettük be a Veres-tút az insuffláláshoz, illetve itt történt a kameratrokár behelyezése is, mert ezt a pontot tekintik sokan a laparoszkópiában legbiztonságosabb behatolási helynek. Az epigastrialisan és a bal oldalon, a köldök magasságában behelyezett portokkal jó triangulatio volt létrehozható, és a helyzet ergonómiai szempontból is ideális volt. 




1. ábra A: A köldökfistulába helyezett szonda. B: A peritoneum alatt látható az urachusvezeték. C: Az urachusvezeték a peritoneum megnyitása után.
D: Az urachus klippelése a hólyagnál

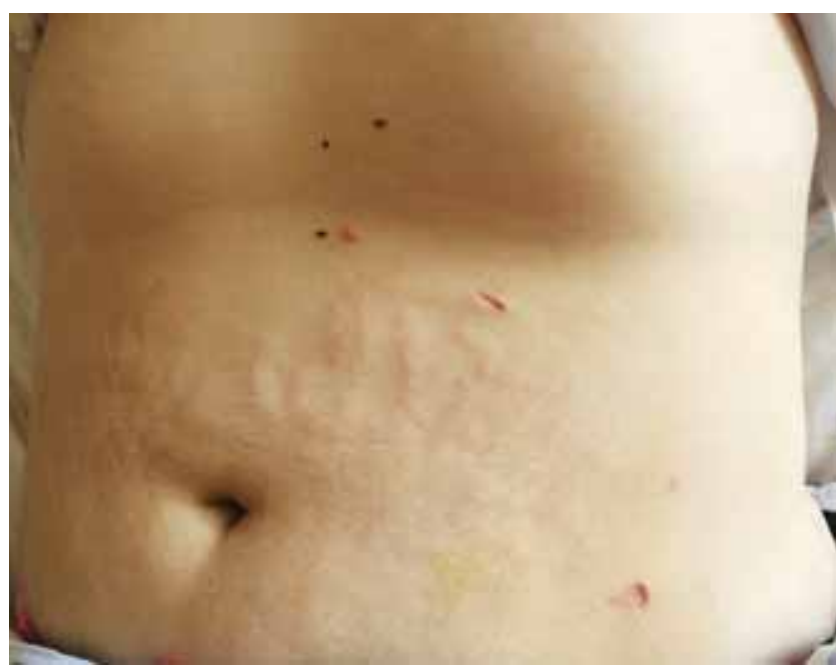

2. ábra

| A kozmetikai eredmény 4 héttel a mútét után

Egyes szerzők a recidíva elkerülésére a köldök kiirtását is szükségesnek tartják [17], mások a hólyag részleges reszekcióját vélik indokoltnak az esetleges malignus átalakulás megelőzésére [18].

Az urachus distalis lezárására javasolják az endoszkópos loop használatát, elkerülendő a fonal, illetve klipp okozta kóképződést [16]. Mivel az általunk használt műanyag klipp a lumenen kívül helyezkedik el, illetve cholecystectomiánál az elmúlt 20 év alatt nem figyelték meg epeúti kövek kialakulását, ezért nem tartottuk indokoltnak endo-loop használatát.

Egyes közleményekben a mútéthez hólyagkatétert helyeznek be. Előnyként említik, hogy feltöltésével intraoperatívan a hólyag jobban látható, ami elősegíti az urachus teljes kiirtását. Sok esetben a katétert a posztoperatív 3. napig, de akár 10. napig is bent hagyják [16]. Mivel hasi sebészeti tapasztalataink alapján az epeutak biztonsággal lezárhatók a klippel, ezért nem tartottuk indokoltnak hólyagkatéter felhelyezését, s ennek köszönhetően a beteget már az első posztoperatív napon elengedtük.

A mütéti szövődményeket legrészletesebben Naiditch és munkatársai cikke tárgyalja: 34, hagyományosan és laparoszkóppal operált beteg 15\%-ánál alakult ki posztoperatív szövődmény. Leggyakrabban sebfertőzés és umbilicalis sérv jelentkezett, de majdnem 10\%-ban számolnak be az urachus sikertelen eltávolításáról. Emellett hólyagvarrat-elégtelenséget, illetve hólyagdiverticulumot és következményes hólyagrupturát is említenek [19].

Összefoglalva: A ductus urachus persistens ellátása a technika előnyei miatt laparoszkóppal ajánlott. 
Anyagi támogatás: A közlemény megírása anyagi támogatásban nem részesült.

Szerzői munkamegosztás: L. P.: A mütét elvégzése és a kézirat elkészítése. H. L.: A kézirat ellenőrzése. A cikk végleges változatát a szerzők elolvasták és jóváhagyták.

Érdekeltségek: A szerzőknek nincsenek érdekeltségeik.

\section{Irodalom}

[1] Blichert-Toft, M., Nielsen, O. V.: Congenital patient urachus and acquired variants. Diagnosis and treatment. Review of the literature and report of five cases. Acta Chir. Scand., 1971, 137(8), 807-814.

[2] Galati, V., Donovan, B., Ramji, F., et al.: Management of urachal remnants in early childhood. J. Urol., 2008, 180(4 Suppl.), 1824-1827.

[3] Sato, H., Furuta, S., Tsuji, S., et al.: The current strategy for urachal remnants. Pediatr. Surg. Int., 2015, 31(6), 581-587.

[4] Yohannes, P., Bruno, T., Pathan, M., et al.: Laparoscopic radical excision of urachal sinus. J. Endourol., 2003, 17(7), 475-479.

[5] Robert, Y., Hennequin-Delerue, C., Chaillet, D., et al.: Urachal remnants: sonographic assessment. J. Clin. Ultrasound, 1996, 24(7), 339-344.

[6] Blichert-Toft, M., Nielsen, O. V.: Congenital patient urachus and acquired variants. Diagnosis and treatment. Review of the literature and report of five cases. Acta Chir. Scand., 1971, 137(8), 807-814

[7] Sheldon, C. A., Clayman, R. V., Gonzalez, R., et al.: Malignant urachal lesions. J. Urol., 1984, 131(1), 1-8.

[8] Mesrobian, H., Zacharias, A., Balcom, A., et al.: Ten years of experience with isolated urachal anomalies in children. J. Urol., $1997,158(3), 1316-1318$

[9] Widni, E. E., Hollwarth, M. E., Haxbija, E. Q.: The impact of preoperative ultrasound on correct diagnosis of urachal remnants in children. J. Pediatr. Surg., 2010, 45(7), 1433-1437.
[10] Choi, צ. J., Kim, J. M., Ahn, S. צ., et al.: Urachal anomalies in children: a single center experience. Yonsei Med. J., 2006, 47(6), 782-786.

[11] McCollum, M. O., MacNeily, A. E., Blair, G. K.: Surgical implications of urachal remnants: presentation and management. J. Pediatr. Surg., 2003, 38(5), 798-803.

[12] Hüttl, T.: A rare developmental abnormality of the abdominal wall; ectopia chordae ductus urachi. [A hasfal ritka fejlődési rendellenessége: ectopias ductus urachus húr.] Magy. Seb., 1954, 7(3), 195-197. [Hungarian]

[13] Vastyán, A., Pintér, A.: Patent urachus in childhood - clinical overview. [Az urachuszjárat záródási rendellenességei gyermekkorban - klinikai áttekintés.] Orv. Hetil., 1992, 133(11), 653656. [Hungarian]

[14] Trondsen, E., Reiertsen, O., Rosseland, A. R.: Laparoscopic excision of urachal sinus. Eur. J. Surg., 1993, 159(2), 127-128.

[15] Patrzyk, M., Glitsch, A., Schreiber, A., et al.: Single-incision laparoscopic surgery as an option for the laparoscopic resection of an urachal fistula: first description of the surgical technique. Surg. Endosc., 2010, 24(9), 2339-2342.

[16] Siow, S. L., Mahendran, H. A., Hardin, M.: Laparoscopic management of symptomatic urachal remnants in adulthood. Asian J. Surg., 2015, 38(2), 85-90.

[17] Araki, M., Saika, T., Araki, D., et al.: Laparoscopic management of complicated urachal remnants in adults. World J. Urol., 2012, 30(5), 647-650.

[18] Uyama, R., Yoshizawa, Y., Sasaya, S., et al.: Laparoscopic resection of urachal remnant with plasty of umbilicus: report of five cases. J. Jpn. Surg. Assoc., 2004, 65(5), 1371-1375.

[19] Naiditch, J. A., Radhakrishnan, J., Chin, A. C.: Current diagnosis and management of urachal remnants. J. Pediatr. Surg., 2013, $48(10), 2148-2152$.

(Lukovich Péter dr., Budapest, Üllői út 78., 1082 e-mail: lukovich66@gmail.com)

\section{Tisztelt Szerzőink, Olvasóink!}

Az Orvosi Hetilapban megjelenő/megjelent közlemények elérhetőségére több lehetőség kínálkozik.

Rendelhető különlenyomat, melynek áráról bővebben a www.akkrt.hu honlapon (Folyóirat Szerzőknek, Különlenyomat menüpont alatt) vagy Szerkesztőségünkben tájékozódhatnak.

A közlemények megvásárolhatók pdf-formátumban is, illetve igényelhető Optional Open Article (www.oopenart.com).

Adott díj ellenében az online közlemények bárki számára hozzáférhetők honlapunkon (a közlemények külön linket kapnak, így más oldalról is linkelhetővé válnak).

Bővebb információ a hirdetes@akkrt.hu címen vagy különlenyomat rendelése esetén a Szerkesztőségtől kérhető. 